\title{
Different host plant utilization ability of two closely related Melitaea species (Lepidoptera: Nymphalidae)
}

\author{
JÁnos P. TÓTH ${ }^{1}$, Judit BERECZKI², Zsolt VÉGVÁRI ${ }^{3}$, EdIT JUHÁSZ² and ZoLTÁN VARGA² \\ ${ }^{1}$ Research Institute for Viticulture and Oenology, Tarcal, Könyves Kálmán Str. 54., H-3915 Tarcal, Hungary; \\ e-mail: acutiformis@yahoo.com \\ ${ }^{2}$ Department of Evolutionary Zoology \& Human Biology, Institute of Biology \& Ecology, University of Debrecen, Debrecen, \\ Hungary; e-mails: bereczki.judit@gmail.com; batoriedit@yahoo.com; zvarga@tigris.unideb.hu \\ ${ }^{3}$ Department of Conservation Zoology, University of Debrecen - Hortobágy National Park Directorate, Sumen Str. 2, \\ H-4024 Debrecen, Hungary; e-mail: vegvari@hnp.hu
}

Key words. Lepidoptera, Nymphalidae, Melitaea phoebe, Melitaea ornata, Cirsium pannonicum, Cirsium arvense, Centaurea scabiosa, life history, plant-insect interaction, multiple mating, allozyme

\begin{abstract}
In natural systems plant-insect interactions are influenced by several factors. For instance plants could be characterised by the presence of defensive chemicals and herbivores are forced to evolve resistance against them. There are several studies on induced plant defence, which indicate it can mediate competition between herbivorous insects, shaping host plant choice and community structure. Therefore, realized host plant use can be much narrower than the potential one. A laboratory experiment was done to clear up the possible difference in host plant utilization ability of Melitaea phoebe and Melitaea ornata, especially their utilization of Cirsium pannonicum. The caterpillars were reared individually on three different species of host plant (Ci. pannonicum, Ci. arvense and Centaurea scabiosa). The weights of the larvae were measured every second day and the data analysed using ANOVA. M. phoebe caterpillars developed well and all pupated when fed on Cirsium arvense and Centaurea scabiosa, whereas those fed on Cirsium pannonicum developed poorly and $10 \%$ died. In contrast, $M$. ornata developed well on $\mathrm{C} i$. pannonicum and the other two host plants. Despite this $M$. ornata was only found on Ci. pannonicum in Hungary.
\end{abstract}

\section{INTRODUCTION}

In natural systems plant-insect interactions are influenced by several factors. On the one hand, many plants are characterised by the presence of defensive chemicals (Ehrlich \& Raven, 1964; Häggström \& Larsson, 1995; Dobler et al., 1996; Monique, 2001; Wahlberg, 2001). These substances form part of the plant's defence system and affect herbivores in different ways, e.g. they can attract predators or parasitoids of herbivores (Vet \& Dicke, 1992), as well as having direct effects, which may be toxic, anti-digestive, anti-nutritive and deterrent (Bernays \& Graham, 1988; Jaenike, 1990; Wittstock \& Gershenzon, 2002; Kessler \& Halitschke, 2007). Up to now, several studies have dealt with induced plant defence, which can mediate competition between herbivorous insects (Ohgushi, 2005; Denno \& Kaplan, 2006; Kessler \& Halitschke, 2007) shaping host plant choice and community structure (Jaenike, 1990; Kaplan \& Denno, 2007). Therefore, the realized host plant use could be much narrower than the potential one (Jaenike, 1990).

On the other hand, herbivores are forced to evolve resistance to plants' defensive chemicals, for instance by means of detoxifying mechanisms. When a novel detoxifying mechanism arises, it will open up a new array of potential host plants, consisting of all those that produce the now less harmful chemical. These food plants constitute a biochemical group, but need not be related phylogenetically as unrelated plants can also have the same defensive chemicals. It follows that herbivores are often not adapted to a single plant species but to a particular type of secondary metabolite, as is the case in Blepharida beetles (Becerra, 1997) and pierid butterflies (Wheat et al., 2007).

The biochemistry of host plant specialization in Melitaeini butterflies is well studied and their adaptation to food plant chemistry is more conservative than the taxonomic relations between Melitaea species and their host plants (Wahlberg, 2001). Most of these food plants contain irido-glycosides with a few exceptions, including the family Asteraceae, the host plants of the Melitaea phoebe species group.

The most well-known species in this group is Melitaea phoebe ([Denis \& Schiffermüller], 1775) (Knapweed fritillary), which occupies an almost continuous area from North Africa across southern and central Europe to northeastern China. M. phoebe and its subspecies are generally bivoltine and oligophagous, and feed on host plants belonging to the family Asteraceae (Table 1).

In Hungary, M. phoebe is a widely distributed, common species. In natural and semi-natural habitats it feeds on various Centaurea species. Caterpillars were also collected from Cirsium pannonicum in the Aggtelek Karst area (North-East Hungary). In ruderal habitats, caterpillars mostly feed on Cirsium arvense, Cirsium vulgare and were also found on various Carduus species.

In general, host plant use by herbivores may differ greatly in different parts of its distribution as it is not uncommon that an oligophagous species become specialist, especially 
TABLE 1. Known host plants of Melitaea phoebe.

\begin{tabular}{lcc}
\hline Region & Host plant species & Citation \\
\hline Europe & $\begin{array}{c}\text { Centaurea } \text { spp. (in most } \\
\text { of the literature is } \text { C. scabiosa) }\end{array}$ & $\begin{array}{c}\text { (Ebert \& Rennwald, 1991; Settele et al., 2005; Russell et } \\
\text { al., 2007; Varga, 2007; Tolman \& Lewington, 2008) }\end{array}$ \\
\hline $\begin{array}{l}\text { Russia } \\
\begin{array}{l}\text { Siberia (Russian Republic } \\
\text { of Buryatia) }\end{array}\end{array}$ & $\begin{array}{c}\text { Inula } \text { spp., } \text { Rhapnticum } \text { spp., Serratula } \text { spp. } \\
\text { (Gorbunov \& Kosterin, 2007; Kuznetsov, 2011) }\end{array}$ \\
\hline $\begin{array}{l}\text { Hungary } \\
\text { Sentaurea scabiosa, Centaurea sadleriana, },\end{array}$ & (Wahlberg et al., 2001) \\
\hline
\end{tabular}

in marginal parts of its distribution (Fielding \& Coulson, 1995; Martin \& Pullin, 2004a, b). This is the case in Melitaea ornata Christoph, 1893 (Eastern knapweed fritillary), whose known area is disjunct ranging from the Levant across Asia Minor, the Balkans to southern Italy and Sicily as well as the Carpathian Basin, but recently it has been indicated from Northern Iran, southern Russia (Volgograd region, South-Urals) and Eastern Kazakhstan (Tóth et al., 2013). It feeds on Asteraceae but its food plants differ regionally (Table 2).

Based on a review of museum specimens and field surveys, $M$. phoebe and M. ornata can co-occur in the same habitat, but the ratio of these two species is very variable. In the eastern part of the Mediterranean region Melitaea ornata is usually a more frequent species than M. phoebe. In the Carpathian Basin, on the edge of the distribution area, $M$. ornata has become a more localised species than M. phoebe, which can colonise more northerly parts of the western Palaearctic region.

In Hungary, the ratio of the two species in the same habitats has been surveyed (Tóth et al., 2011). The results show that $M$. ornata occurs in higher numbers only in those habitats where its only known food plant (Cirsium pannonicum) is abundant, despite the fact that there are several Asteraceae (Carduus sp., Centaurea sp.) there that are used as food plants in the Mediterranean area. In these habitats M. phoebe has relatively low abundance although caterpillars were recorded feeding on $C i$. pannonicum.

The aim of the study was to clear up the possible difference in host plant utilization ability of Melitaea phoebe and Melitaea ornata, especially that of Cirsium pannonicum.

Based on Tóth et al. (2011) we assumed that Melitaea phoebe would develop less well on Cirsium pannonicum than $M$. ornata. This hypothesis was tested using a laboratory experiment.

\section{MATERIAL AND METHODS}

Two mated Melitaea phoebe females were collected from Eastern Hungary in spring 2011. Females were kept in a net-cage in the field in which there were nectar sources and different food plants. In total, the females laid $\sim 300$ eggs on the same Cirsium arvense plant. One hundred caterpillars were randomly chosen for the experiment.

M. ornata caterpillars in the second larval stage were collected in field from a single nest. Since this species is localized and vulnerable in Hungary only 30 larvae were used in the experiment.

The caterpillars were reared individually to pupation in $100 \mathrm{ml}$ plastic cups kept under standard laboratory conditions $\left(25^{\circ} \mathrm{C}, 18 \mathrm{~L}\right.$ :6D). Three different species of food plants were used: Cirsium arvense (main host of Melitaea phoebe in lowland areas), Centaurea scabiosa (main food plant of $M$. phoebe in hilly regions) and $\mathrm{Ci}$. pannonnicum, the only known food plant of Melitaea ornata in Hungary. Only leaves were used for feeding. The cups were checked and provided with fresh leaves every day.

The weight of the larvae was measured every second day with an assay scale. Larval duration was defined as the period from the day when the experience started until the pupation. Pupae were collected and weighted $24 \mathrm{~h}$ after ecdysis and then replaced in the plastic cups until adult emergence. Sexes of the individuals were determined based on the emerged imagoes. Larval survival was calculated for each treatment (food plant). Relative growth rate (RGR, in milligrams per milligram per day), which quantifies mass gained per unit time, was calculated based on an exponential growth model (Lederhouse et al., 1992; Nitao et al., 1991): $\mathrm{RGR}=\left(\ln \left(\mathrm{W}_{\mathrm{P}}\right)-\ln \left(\mathrm{W}_{\mathrm{I}}\right)\right) / \mathrm{D}$ where $\mathrm{W}_{\mathrm{P}}$ is pupal mass, $\mathrm{W}_{\mathrm{I}}$ is initial larval mass, and $\mathrm{D}$ is larval duration up to the pupal stage. The weights and the growth rates were analysed using the ANOVA in R statistical (R-Core-Team, 2013) computing environment.

As polyandry occurs in many nymphalid butterflies (Scot, 1972; Wiklund et al., 2003) and we had no information on the number of males which mated with the females we used an analysis of enzymes to obtain information on the genetic variability of our experimental "population" and to compare it with that in natural populations. We obtained enzyme data from 93 experimental Melitaea phoebe imagoes and five natural populations (Table 3). Allozyme polymorphism was studied at 14 loci (aldehyde oxydase (Aox), esterase (Est), glucose-6-phosphate dehydrogenase (G6pdh), glutamate oxalacetate transaminase (Got), a-glycerophosphate dehydrogenase (Gpdh), hexokinase (Hk), isocitrate dehydrogenase (Idh), malate dehydrogenase (Mdh), malic enzyme (Me), phosphoglucose isomerase (Pgi), phosphoglucomutase (Pgm), 6-phosphogluconate dehydrogenase (6pgdh)

TABLE 2. Known host plants of Melitaea ornata.

\begin{tabular}{lcc}
\hline Region & Host plant species & Citation \\
\hline $\begin{array}{l}\text { Sicily } \\
\text { Greece }\end{array}$ & Centaurea deusta, C. busambarensis, C. solstitialis & (Russell et al., 2007) \\
\hline Hungary & Centaurea achaia, C. raphanina, C. salonita, \\
Volgograus nutans & (Russell \& Pamperis, 2011; Russell et al., 2007) \\
\hline
\end{tabular}




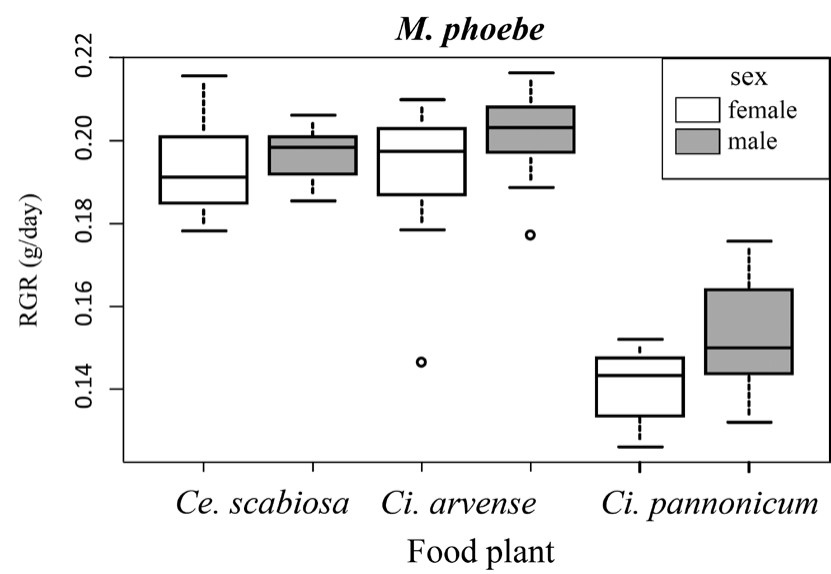

Fig. 1. Relative growth rate (RGR) of Melitaea phoebe caterpillars fed on three different host plants. The males developed slightly faster. Cirsium pannonicum was the worst food-plant for M. phoebe and the difference is significant $(\mathrm{p}<0.001)$.

and superoxid dismutase (Sod1, Sod2)) by vertical polyacrylamide gel electrophoresis. Thoraxes homogenized in $350 \mu \mathrm{l}$ of extraction buffer were used to study G6pgdh, Got, Gpdh, Hk, Idh, Mdh, Me, Pgi, Pgm, Sod1 and Sod2. Abdomens homogenized in $400 \mu \mathrm{l}$ of extraction buffer were used to analyse Aox, Est and $6 p g d h$. The extraction buffer, the electrophoresis buffer systems and running conditions, together with the staining solutions were used according to Bereczki et al. (2005).

Genotypes of the individuals were scored according to their enzyme pattern. Genotype and allele frequencies were calculated on the basis of banding patterns. Measures of genetic variation (Table 3) were calculated for each sample using GenAlEx 6.41 (Peakall \& Smouse, 2006) and FSTAT 2.9.3.2 (Goudet, 1995). Since the size of the experimental population exceeded that of the studied natural populations we also calculated two additional parameters, which do not depend on the number of individuals: (i) the effective number of alleles $\left(n_{E}\right)$, which is the number of equally frequent alleles that it would take to achieve the given level of effective heterozygosity in the population; (ii) allelic richness (Ar) was measured using Hurlbert's rarefaction method (1971) where the expected value of $n_{A}$ is the number of alleles that would occur in a subsample of the given sample with $\mathrm{N}_{\mathrm{s}}=$ $\mathrm{N}_{\min }$ (where $\mathrm{N}_{\min }$ is the size of the smallest sample of the study in question; in our case $\mathrm{N}_{\min }=14$ ).

Based on the most variable enzyme locus (6pgdh), we calculated the possible minimal number of parents applying a new computational approach as follows. First, we constructed all possible genotypes from the presence of unique alleles. Then based on Punnett's tables we searched all parental genotypes permu-

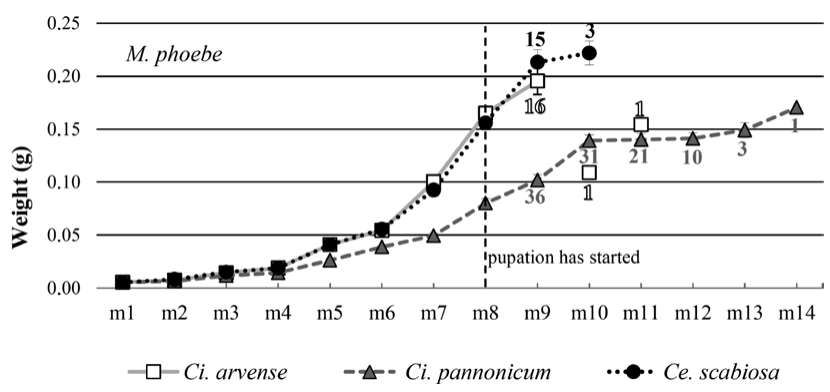

Fig. 2. Average weights of Melitaea phoebe caterpillars fed on three different host plants. There were no significant differences between the weights of the different groups at the start of the experiment. After the $8^{\text {th }}$ measurement some of the caterpillars started to pupate. The numbers indicate the non-pupated caterpillars. The caterpillars showed slightly better development on Centaurea scabiosa than Cirsium arvense, while Cirsium pannonicum was the worst host plant in this comparison.

tationally. In the next step, we formulated a complete set of all pairs of possible parent types. To find the minimum number of parents that could provide the experimental offspring set, we selected groups of parents starting with $n=2$ and increased the number of set elements by one in each further step. In each step we selected $n$ elements of the complete set of parents and derived all possible offspring types. When the offspring set of the selected set of parents' genotypes included all of the genotypes of the experimental offspring, we considered $n$ the minimum number of parents necessary for producing the number of unique genotypes in the offspring of our experiment.

\section{RESULTS}

\section{Enzyme studies}

All indices of polymorphism indicated a high level of variation in the M. phoebe populations (Table 3). Overall, the average number of alleles per locus was about 2.5 , the average frequency of heterozygotes was almost $20 \%$ and the percentage of polymorphic loci was over $70 \%$.

Based on the allozyme data, at least 5 parents were necessary to establish our experimental population. The parameters of genetic variability in the experimental population are close to the measures of variation in natural populations and exceed it in only a few cases (e.g. I, GD, $\mathrm{H}_{\mathrm{o}}$ in Table 3). In the experimental population the observed heterozygosity $\left(\mathrm{H}_{\mathrm{o}}\right)$ and the effective number of alleles $\left(\mathrm{N}_{\mathrm{e}}\right)$, which does not depend on the number of individuals,

TABLE 3. The parameters of the genetic diversity of the M. phoebe populations. Zab - Zabanyik, 2011/05/25; Egy - Egyek, 2012/05/2606/07; Szh - Szőlőhegy, 2000/05/06; Bor - Borház-tető, 2006/06/01; Mal - Mályvád, 1999/07/21; Exp - experimental "population". $\mathrm{N}=$ the number of individuals; $\mathrm{N}_{\mathrm{a}}=$ the number of different alleles; $\mathrm{I}=$ Shannon's information index $=-1 * \operatorname{Sum}(\mathrm{pi} * \mathrm{Ln}(\mathrm{pi})$ ); GD = gene diversity; $\mathrm{H}_{\mathrm{o}}=$ observed heterozygosity $=$ No. of Hets $/ \mathrm{N} ; \mathrm{P} \%=$ percentage of polymorphic loci; $\mathrm{N}_{\mathrm{e}}=$ the number of effective alleles $=1 /\left(\mathrm{Sum}_{\mathrm{pi}}{ }^{\wedge} 2\right) ; \mathrm{Ar}=$ allelic richness.

\begin{tabular}{lcccccccc}
\hline Population & $\mathrm{N}$ & $\mathrm{N}_{\mathrm{a}}$ & $\mathrm{I}$ & $\mathrm{GD}$ & $\mathrm{H}_{\mathrm{o}}$ & $\mathrm{P}_{95} \%$ & $\mathrm{~N}_{\mathrm{e}}$ & $\mathrm{Ar}$ \\
\hline Zab & 14.000 & 2.643 & 0.424 & 0.233 & 0.143 & 85.71 & 1.375 & 2.643 \\
Bor & 15.000 & 2.429 & 0.400 & 0.222 & 0.195 & 64.29 & 1.375 & 2.399 \\
Szh & 20.000 & 2.429 & 0.384 & 0.213 & 0.175 & 71.43 & 1.385 & 2.247 \\
Mal & 15.000 & 2.500 & 0.445 & 0.253 & 0.176 & 78.57 & 1.450 & 2.462 \\
Egy & 20.857 & 2.929 & 0.539 & 0.301 & 0.217 & 100.00 & 1.663 & 2.654 \\
Exp & 90.643 & 2.286 & 0.422 & 0.241 & 0.250 & 57.14 & 1.647 & 1.990 \\
Average & 29.250 & 2.536 & 0.436 & 0.244 & 0.193 & 76.190 & 1.483 & 2.399 \\
\hline
\end{tabular}






Fig. 3. Average weights of Melitaea ornata caterpillars fed on three different host plants. There were no significant differences between the weights of the different groups at the start of the experiment. At the time of the third measurement some of the caterpillars had started aestivating. It seems that Centaurea scabiosa and Cirsium pannonicum are slightly better food plants than $\mathrm{Ci}$. arvense.

are higher than in natural populations (except for $\mathrm{N}_{\mathrm{e}}$ in the Egyek population, although $\mathrm{N}_{\mathrm{e}}$ is only slightly higher in the Egyek population than the experimental population) and higher than the average.

\section{Initial weights}

Based on the first measurements there were no significant differences between the initial weights of the caterpillars ( $p$ $=0.2, \mathrm{~F}=1.4)$ (see: Figs 2, 3). The $M$. phoebe caterpillars weighed $0.0050 \mathrm{~g}$ on average (min. 0.0030, max. 0.0060) when we started the experiment, whereas those of $M$. ornata were $0.0042 \mathrm{~g}$ on average (min. 0.0033, max. 0.0064).

Of the Melitaea phoebe caterpillars that pupated and emerged as butterflies $42.8 \%$ were females and $57.2 \%$ males. The females took slightly longer to complete their development (in average 2 days more) than the males since the females pupated with slightly larger weight than males. The results of the ANOVA indicated that the growth rate was significantly affected by host plant (host plant, $\mathrm{p}<$ $0.001, F=181.16)$ in both sexes (host plant $\times$ sex, $p<$ $0.001, \mathrm{~F}=5.649$ ) (Fig. 1).

The caterpillars developed well on Cirsium arvense and Centaurea scabiosa and all of them pupated, whereas those that fed on Cirsium pannonicum showed a much worse development. All of the caterpillars survived on all of the food plants except $\mathrm{C} i$. pannonicum on which $10 \%$ mortality was recorded. One "outlier" individual was detected in the Cirsium arvense group developed much worse than any of the others (Fig. 2).

Unfortunately, we were not able to prevent the aestivation of the larvae of Melitaea ornata. When the caterpillars reached a critical weight they entered aestivation. Although we only measured the weights four times, we obtained some information on the development of the caterpillars. The larvae fed on Centaurea scabiosa developed faster than those fed on other food plants and the development was the slowest on Cirsium arvense. Between the third and fourth measurements $90 \%$ of the individuals fed on Centaurea scabiosa aestivated, while only $50 \%$ of those fed on Cirsium pannonicum and $10 \%$ of those fed on Cirsium arvense (Fig. 3).

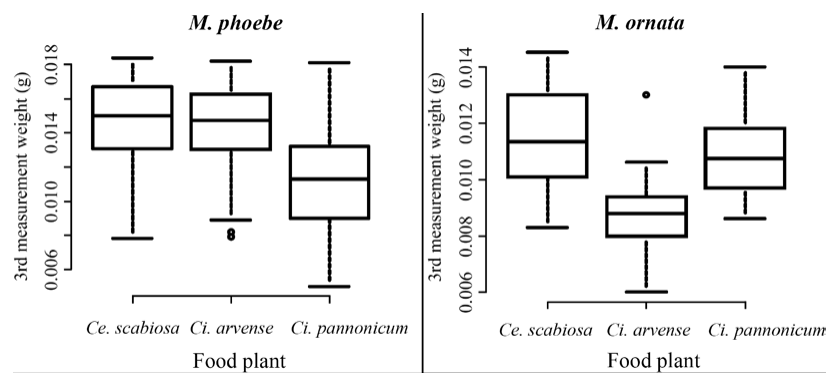

Fig. 4. The weights of the caterpillars at the 3rd measurement. Melitaea phoebe developed much better on Centaurea scabiosa and Cirsium arvense than on Cirsium pannonicum $(\mathrm{p}<0.05, \mathrm{~F}=$ 5.57). In this comparison, the best food plant for M. ornata was Centaurea scabiosa followed by Cirsium pannonicum, while the worst was Cirsium arvense $(\mathrm{p}<0.05, \mathrm{~F}=15.57)$.

Since the initial weights of $M$. phoebe and M. ornata caterpillars were very similar we could compare the weights at the third measurement (Fig. 4). The two species showed very different patterns of host plant utilization. $M$. phoebe caterpillars reached the lowest weights on $\mathrm{Ci}$. pannonicum, while $M$. ornata developed worst on $\mathrm{Ci}$. arvense.

During aestivation $M$. ornata caterpillars woke up and moulted once more, after which their head capsule turned red. In autumn the caterpillars were replaced to field for overwintering but only two survived, probably due to extreme fluctuations in temperature in winter 2011.

\section{DISCUSSION}

In this study the performance of $M$. phoebe and $M$. ornata were tested on Centaurea scabiosa, Cirsium arvense and $\mathrm{Ci}$. pannonicum.

Despite rearing them under standard laboratory conditions all the $M$. ornata caterpillars aestivated on reaching a critical weight. Thus, the monovoltinism of $M$. ornata is probably a genetically determined adaptive trait, which could be advantageous in a Mediterranean climate, in which most of the annual precipitation falls in winter and spring, and animals and plants have to adapt to summer aridity. In lepidopterans, larval aestivation in summer could be a good strategy as it is obvious in some closely related Mediterranean species, such as Melitaea aetherie or M. arduinna. M. ornata caterpillars are highly resilient when they aestivate. They can survive not only the lack of food and humidity but even the cold winters, which are regular in Hungary and Russia (e.g. Volgograd region), where this species also occurs.

Although only the caterpillars of $M$. phoebe completed their development we obtained valuable information on both species' biology and their food plant utilization ability. The M. phoebe "population" studied was very diverse genetically and very similar in this respect to natural populations. Therefore, the genetic variability of the laboratory stock proved to be high enough to draw general conclusions regarding the different host plant utilization ability of M. phoebe.

Based on our results we can conclude that $\mathrm{Ci}$. pannonicum was the worst food plant for $M$. phoebe in our study. The development takes longer time, the final weights were 
significantly lower and $10 \%$ mortality was recorded, thus feeding on $\mathrm{Ci}$. pannonicum has negative consequences for $M$. phoebe caterpillars. The negative effect of lethal toxicity is evident but sub-lethal effects like slower development rate and lower pupal weight could also exert negative effects on the fitness of herbivorous insects (Clancy \& Price, 1987; Benrey \& Denno, 1997; Awmack \& Leather, 2002). Surprisingly, $\mathrm{Ci}$. pannonicum is the only known food plant of $M$. ornata in Hungary, although our results indicate that the population of $M$. ornata studied developed well on Ce. scabiosa and less so on $\mathrm{Ci}$. arvense. Additionally, it is known that $M$. ornata uses several Centaurea species in the Mediterranean region (see: Table 2).

Based on the distribution data and the results of species distribution modelling (Tóth et al., 2013) it is clear that $M$. ornata is a Ponto-Mediterranean-Turkestanian faunal element, which became a localized species with an island-like distribution pattern at the northern margins of its distribution surrounded by more or less continuous populations of M. phoebe. The opposite situation is reported in Turkey (Hesselbarth et al., 1995) and Southern Greece (Russell et al., 2007), where the climate is usually optimal for $M$. ornata and suboptimal for M. phoebe, thus there M. phoebe is the more localized species.

Further studies are needed to clear up the physiological adaptation that has enabled $M$. ornata to utilize $C i$. pannonicum without negative effects. This mechanism could be the key factor in the habitat and food plant specialism of this species in Hungary. According to previous investigations (de Lattin, 1967; Thomas, 1985; Fielding \& Coulson, 1995; Bossart, 2003) the restricted food plant use of marginal populations are mostly explained by the limited availability of food (e.g. Calluna spp. in Northern Atlantic region). It is obvious that this hypothesis does not fit our case. We assume that the food plant specialism of Melitaea ornata in the Carpathian Basin is shaped by suboptimal climate conditions but it also might be influenced by the possible competitive pressure of the more generalist $M$. phoebe.

ACKNOWLEDGEMENTS. We are very grateful to T. Schmitt, M. Nieminen and an anonymous referee for useful suggestions on the manuscript. The study was supported by the OTKA (K84071, K-109223). J.B. was supported by János Bolyai Scholarship of the Hungarian Academy of Sciences. E.J. was supported by the European Union and the State of Hungary, co-financed by the European Social Fund within the framework of TÁMOP4.2.4.A/ 2-11/1-2012-0001 "National Excellence Program". Grateful acknowledgements are due to S. Szabó for collecting samples and Z. Végvári for the useful suggestions on the R script. The support of the Nature Conservation Authorities of Hungary is also greatly appreciated.

\section{REFERENCES}

Awmack C.S. \& Leather S.R. 2002: Host plant quality and fecundity in herbivorous insects. - Annu. Rev. Entomol. 47: 817-844.

BECERRA J.X. 1997: Insects on plants: Macroevolutionary chemical trends in host use. - Science 276: 253-256.
BenRey B. \& Denno R.F. 1997: The slow-growth-high-mortality hypothesis: A test using the cabbage butterfly. - Ecology $\mathbf{7 8}$ : 987-999.

Bereczki J., Pecsenye K., Peregovits L. \& Varga Z. 2005: Pattern of genetic differentiation in the Maculinea alcon species group (Lepidoptera, Lycaenidae) in Central Europe. - J. Zool. Syst. Evol. Res. 43: 157-165.

Bernays E. \& Graham M. 1988: On the evolution of host specificity in phytophagous arthropods. - Ecology 69: 886-892.

BOSSART J.L. 2003: Covariance of preference and performance on normal and novel hosts in a locally monophagous and locally polyphagous butterfly population. - Oecologia 135: 477-486.

Clancy K.M. \& Price P.W. 1987: Rapid herbivore growth enhances enemy attack: sublethal plant defenses remain a paradox. - Ecology 68: 733-737.

De Lattin G. 1967: Grunddriß der Zoogeographie Gustav Fischer, Jena, 602 pp.

Denno R.F. \& Kaplan I. 2006: Plant-mediated interactions in herbivorous insects: mechanisms, symmetry, and challenging the paradigms of competition past. In Ohgushi T., Craig T.P. \& Price P.W. (eds): Ecological Communities: Plant Mediation in Indirect Interaction Webs. Cambridge University Press, Cambridge, pp. 19-55.

Dobler S., Mardulyn P., Pasteels J.M. \& Rowell-Rahier M. 1996: Host-plant switches and the evolution of chemical defense and life history in the leaf beetle genus Oreina. — Evolution 50: 2373-2386.

Ebert G. \& Rennwald E. 1991: Die Schmetterlinge Badenwürttembergs: Tagfalter I. E. Ulmer, Stuttgart, 552 pp.

EHRLICH P.R. \& RAVEN P.H. 1964: Butterflies and plants: a study in coevolution. - Evolution 48: 586-608.

Fielding C.A. \& Coulson J.C. 1995: A test of the validity of insect food-plant and life-history records: Lepidoptera on heather (Calluna vulgaris). - Ecol. Entomol. 20: 343-350.

Gorbunov P. \& Kosterin O. 2007: Butterflies (Hesperioidea \& Papilionoidea) of North Asia (Asian Part of Russia) in Nature. Vol. 2. Rodina \& Fodio, Moscow, 408 pp.

GoudeT J. 1995: Fstat (Version 1.2): A computer program to calculate F-statistics. - J. Hered. 86: 485-486.

HÄGGSTRÖM H. \& LARSSON S. 1995: Slow larval growth on a suboptimal willow results in high predation mortality in the leaf beetle Galerucella lineola. - Oecologia 104: 308-315.

Hesselbarth G., Oorschot H.V. \& Wagener S. 1995: Die Tagfalter der Turkei unter Berücksichtigung der angrenzenden Länder: (Lepidoptera: Papilionoidea and Hesperioidea). Goecke \& Evers, Bochold, $2201 \mathrm{pp}$.

HURLBERT S.H. 1971: The nonconcept of species diversity: A critique and alternative parameters. - Ecology 52: 577-586.

JAENIKE J. 1990: Host specialization in phytophagous insects. Annu. Rev. Ecol. Syst. 21: 243-273.

KAPLAN I. \& DENNo R.F. 2007: Interspecific interactions in phytophagous insects revisited: a quantitative assessment of competition theory. - Ecol. Lett. 10: 977-994.

Kessler A. \& HalitschKe R. 2007: Specificity and complexity: the impact of herbivore-induced plant responses on arthropod community structure. - Curr. Opin. Plant Biol. 10: 409-414.

Kuznetsov G.V. 2011: Some data about biology Melitaea telona Fruhstorfer, 1908 and Melitaea robertsi uvarovi Gorbunov, 1995 (Lepidoptera: Nymphalidae) on Volgograd region. Caucas. Entomol. Bul. 7: 83-84.

Lederhouse R.C., Ayres M.P., Nitao J.K. \& Scriber J.M. 1992: Differential use of lauraceous hosts by swallowtail butterflies, Papilio troilus and P. palamedes (Papilionidae). - Oikos 63: 244-252. 
Martin L.A. \& Pullin A.S. 2004a: Host-plant specialisation and habitat restriction in an endangered insect, Lycaena dispar batavus (Lepidoptera: Lycaenidae) I. Larval feeding and oviposition preferences. - Eur. J. Entomol. 101: 51-56.

Martin L.A. \& Pullin A.S. 2004b: Host-plant specialisation and habitat restriction in an endangered insect, Lycaena dispar batavus (Lepidoptera: Lycaenidae) II. Larval survival on alternative host plants in the field. - Eur. J. Entomol. 101: 57-62.

MonIQUE S.J.S. 2001: Importance of flavonoids in insect-plant interactions: feeding and oviposition. - Phytochemistry 56: 245-252.

Nitao J.K., Ayres M.P., Lederhouse R.C. \& Scriber J.M. 1991: Larval adaptation to lauraceous hosts: geographic divergence in the spicebush swallowtail butterfly. - Ecology 72: 1428 1435.

OHGUSH T. 2005: Indirect interaction webs: herbivore-induced effects through trait change in plants. - Annu. Rev. Ecol. Evol. Syst. 36: 81-105.

Peakall R.O.D. \& Smouse P.E. 2006: Genalex 6: genetic analysis in Excel. Population genetic software for teaching and research. - Mol. Ecol. Notes 6: 288-295.

R-Core-Team 2013: R: A Language and Environment for Statistical Computing. R Foundation for Statistical Computing.

Russell P. \& PAMPERIS L.N. 2011: A reassessment of the presence of Melitaea phoebe ([Denis \& Schiffermüller], 1775)(Lepidoptera: Nymphalidae) in the Aegean islands. - Entomol. Gaz. 62: 139-158.

Russell P., Tennent W.J., Pateman J., Varga Z., Benyamini D., Pe’er G., BÁlint Z. \& Gascoigne-Pees M. 2007: Further investigations into Melitaea telona Frushstorfer, 1908 (= ogygia Frushstorfer, 1908 = emipunica Verity, 1919) (Lepidoptera: Nymphalidae), with observations on biology and distribution. - Entomol. Gaz. 58: 137-166.

Sсот J.A. 1972: Mating of butterflies. - J. Res. Lepidopt. 11: 99-127.

Settele J., Steiner R., Reinhardt R. \& Feldmann R. 2005: Schmetterlinge Die Tagfalter Deutschlands Ulmer, Stuttgart $256 \mathrm{pp}$.
Thomas C.D. 1985: Specializations and polyphagy of Plebejus argus (Lepidoptera, Lycaenidae) in North-Wales. - Ecol. Entomol. 10: 325-340.

Tolman T. \& Lewington R. 2008: The Most Complete Guide to the Butterflies of Britain and Europe. Harper Collins, London $384 \mathrm{pp}$.

Tóth J.P., Bereczki J., Spring N. \& Varga Z. 2011: Dispersal ability and habitat selection in Melitaea telona kovacsi Varga, 1967 and M. phoebe (Denis \& Schiffermüller, 1775) (Nymphalidae) in steppe grassland. - Nota Lepid. 33: 199-207.

Tóth J.P., VARga K., VéGVÁri Z. \& VARGa Z. 2013: Distribution of the Eastern knapweed fritillary (Melitaea ornata Christoph, 1893) (Lepidoptera: Nymphalidae): past, present and future. J. Insect Conserv. 17: 245-255.

VARGA Z. 2007: The Kovács' Fritillary (Melitaea telona kovacsi Varga, 1967) in the Carpathian basin. In László F. (ed.): The Genesis of the Wildlife of the Carpathian Basin. The Zoological Values and Faunal Genesis. Hungarian Natural History Museum, Budapest, pp. 143-152.

Vet L.E.M. \& Dicke M. 1992: Ecology of infochemical use by natural enemies in a tritrophic context. - Annu. Rev. Entomol. 37: $141-172$.

WAHLBERG N. 2001: The phylogenetics and biochemistry of hostplant specialization in Melitaeine butterflies (Lepidoptera: Nymphalidae). - Evolution 55: 522-537.

Wahlberg N., Kullberg J. \& Hanski I. 2001: Natural history of some Siberian melitaeine butterfly species (Nymphalidae: Melitaeini) and their parasitoids. - Entomol. Fenn. 12: 72-77.

Wheat C.W., Vogel H., Wittstock U., Braby M.F., Underwood D. \& Mitchell-Olds T. 2007: The genetic basis of a plant-insect coevolutionary key innovation. - Proc. Natl. Acad. Sci. U.S.A. 104: 20427-20431.

Wiklund C., Gotthard K. \& Nylin S. 2003: Mating system and the evolution of sex-specific mortality rates in two nymphalid butterflies. - Proc. R. Soc. Lond. 270: 1823-1828.

Wittstock U. \& Gershenzon J. 2002: Constitutive plant toxins and their role in defense against herbivores and pathogens. Curr. Opin. Plant Biol. 5: 1-8.

Received April 26, 2014; revised and accepted August 19, 2014 Prepublished online October 15, 2014 